\title{
Luminescence Chronology of the Schwalbenberg II Loess in the Middle Rhine Valley
}

\author{
Manfred Frechen, Wolfgang Schirmer
}

Abstract:

\begin{abstract}
The multiple aliquot protocol based Infrared Stimulated Luminescence (IRSL) and thermoluminescence (TL) data and those of the single aliquot regenerative protocol based post-IR IRSL at $225^{\circ} \mathrm{C}$ and fading-corrected IRSL at $50^{\circ} \mathrm{C}$ show that anomalous fading is only a minor problem for the loess and loess derivatives at the Schwalbenberg II loess section. Therefore, it is very likely that multiple aliquot based protocols, which were applied commonly in the 1990s for loess from the Middle Rhine Valley, yielded reliable IRSL and TL age estimates up to an age of about 70-80 ka. The loess/palaeosol sequence of the Schwalbenberg II loess section shows a remarkable detailed Weichselian Middle Pleniglacial (MIS 3) record. A detailed and more reliable chronological framework was set up by luminescence dating methods for the loess record resulting in four major accumulation periods for this last glacial record. The chronological results give further evidence for the litho-pedological correlation of the Hesbaye Formation and the Ahrgau Formation to MIS 2 and MIS 3, respectively. The Keldach Formation is designated to correlate to MIS 4 by means of litho-pedostratigraphy but gives deposition ages between 55 and $45 \mathrm{ka}$, which does suggest a correlation to MIS 3.
\end{abstract}

[Lumineszenz-Chronologie des Schwalbenberg II-Lösses im Mittelrheintal]

Kurzfassung:

Der Vergleich von „multiple aliquot“ Protokoll basierten IRSL- und TL-Altern mit denen von „single aliquot regenerative“ Protokollen mittels des post-IR IRSL $\left(225^{\circ} \mathrm{C}\right)$ und fading-korrigierten IR $\left(50^{\circ} \mathrm{C}\right)$ zeigt, dass Signalverlust durch anomales Ausheilen für Lösse und Lössderivate des Schwalbenberg II Profils ein geringes Problem darstellt. Aus diesem Grund ist es sehr wahrscheinlich, dass auf „multiple aliquot“ Messprotokollen beruhende Lumineszenz-Datierungen, die in den 1990er Jahren im allgemeinen für Lösse aus dem Mittelrheingebiet angewendet wurden, bis zu einem Alter von 70-80 ka innerhalb der 1-sigma Fehlerabweichung verlässliche IRSL und TL-Alter ergeben haben. Die Löss-/Paläobodensedimente des Schwalbenberg II Lössprofils zeigen einen bemerkenswert detaillierte weichselzeitliche mittelpleniglaziale Abfolge, die mit dem marinen Sauerstoffisotopenstadium 3 korreliert wird. Ein verlässlicher chronologischer Rahmen wurde durch Lumineszenz-Datierungsmethoden bestimmt. Vier Löss-Hauptakkumulationsphasen konnten für die letztglaziale Abfolge vom Schwalbenberg nachgewiesen werden. Die chronologischen Ergebnisse unterstützen die litho-pedologische Korrelation der Hesbaye Formation mit MIS 2 und der Ahrgau Formation mit MIS 3. Aufgrund von litho-pedologischen Befunden wird die Keldach Formation mit MIS 4 korreliert. Die Lumineszenz-Alter von 55 bis 45 ka legen jedoch eine Korrelation mit MIS 3 nahe.

Keywords: $\quad$ loess, luminescence dating, Pleistocene, Germany, climate change

Addresses of authors: M. Frechen, Leibniz Institute for Applied Geophysics (LIAG), Geochronology and Isotope Hydrology, Stilleweg 2, 30655 Hannover, Germany. E-Mail: Manfred.Frechen@liag-hannover.de; W. Schirmer, Dept. of Geology, Heinrich Heine University Düsseldorf. Postal address: 91320 Wolkenstein 24, Germany. E-Mail: schirmer@uni-duesseldorf.de

\section{Introduction}

In Central Europe, loess/palaeosol sequences provide excellent high-resolution terrestrial archives of climate and environment change for the past 130,000 years, the time span of the Upper Pleistocene. Thermoluminescence (TL) and Infrared Stimulated Luminescence (IRSL) dating me-thods have been successfully applied for numerous Upper Pleistocene loess records in Central Europe (e.g. FreChEN, 1994; Frechen et al.. 2003; SCHMidT et al. 2011; ZöLLER et al. 1994). During the 1990s mainly multiple aliquot additive dose (MAAD) protocols and multiple aliquot regeneration dose (MARD) protocols were applied to determine the equivalent dose $\left(D_{e}\right)$ values for IRSL and TL dating. The latter studies provided apparently reliable numerical age estimates up to about $100 \mathrm{ka}$. In the past 15 years, luminescence dating of sediments has been significantly improved by establishing single aliquot regenerative (SAR) protocols for determining the equivalent dose. SснмidT et al. (2011) re-investigated the loess and its derivatives from the Tönchesberg section in the Middle Rhine area and found their single aliquot regenerative (SAR) protocol results in excellent agreement with those determined earlier by the MAAD and MARD protocols up to about $70-80 \mathrm{ka}$, and thus confirmed previously published results from Frechen $(1992,1994)$ and ZöLLER et al. (1991) for the Tönchesberg section. The results of SснміDT et al. (2011) show that reliable age estimates up to about 70 ka can be obtained by quartz Optically Stimulated Luminescence (OSL) and up to about 200 ka by feldspar pulsed post-IR IRSL for the last glacial and penultimate glacial loess in the Middle Rhine area, respectively. Therefore, we continue to study the application of multiple aliquot IRSL and TL with those of SAR post-IR IRSL on polymineral fine-grain material from the Schwalbenberg loess.

At the Schwalbenberg section, which is located in the Middle Rhine valley, a very detailed Middle Weichselian loess record is exposed (SCHIRMER 1990, 1991, 2000a, b, 2011). Altogether 44 samples were investigated, resulting in more 


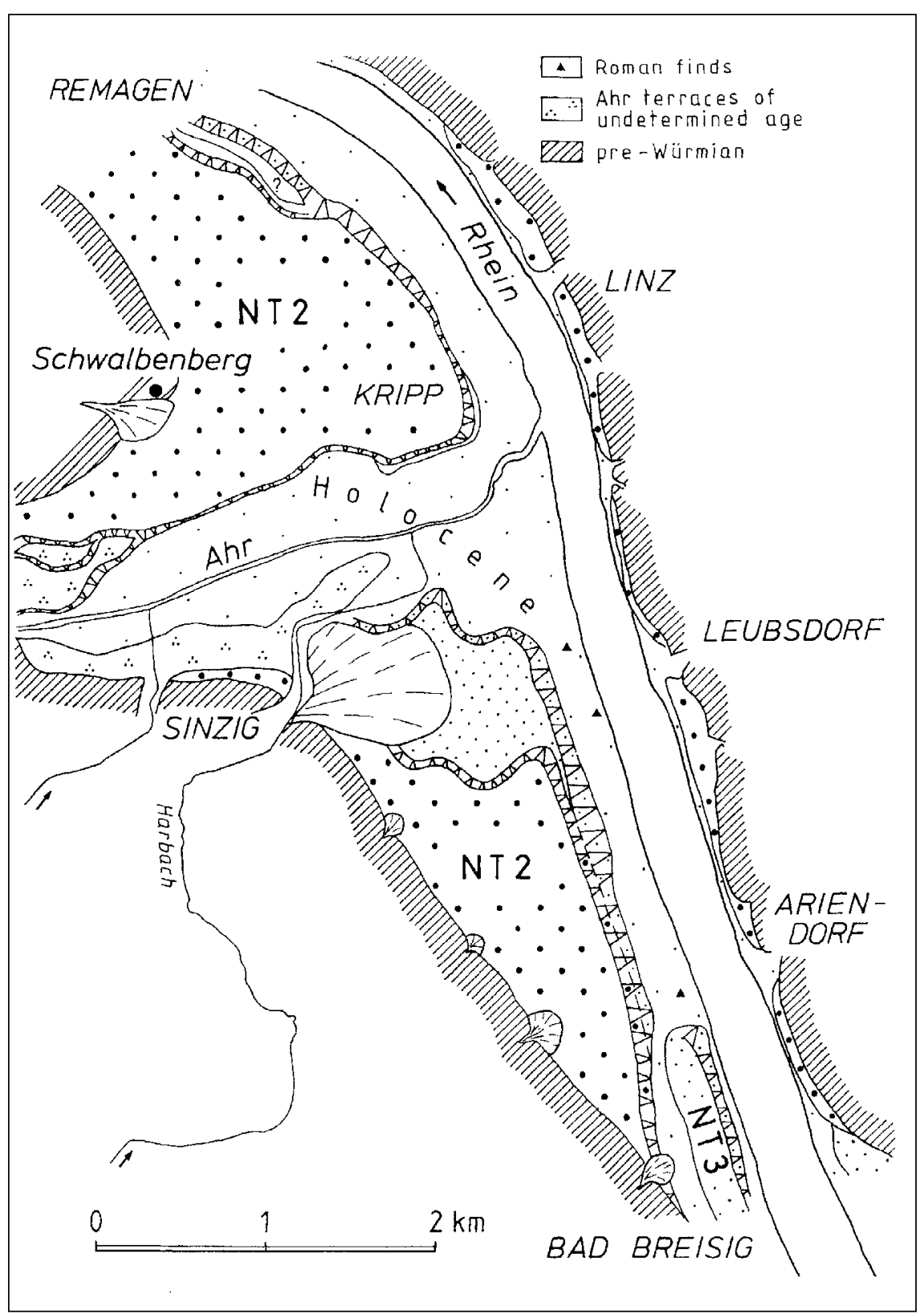

Fig. 1: Map showing the location of the Schwalbenberg section in the Middle Rhine Valley (from SCHIRMER 1995: 530, modified).

Abb. 1: Lage des Aufschlusses Schwalbenberg im Mittelrheintal (aus SCHIRMER 1995: 530, verändert). than 140 IRSL and TL age estimates applying multiple aliquot additive dose and multiple aliquot regeneration dose protocols. Four samples were also investigated by single aliquot regenerative (SAR) protocols including IRSL at $50^{\circ} \mathrm{C}$ and post-IR IRSL at $225^{\circ} \mathrm{C}$. Fading correction was applied for the IRSL $50^{\circ} \mathrm{C}$ signal.

The aim of this study is to set up a more reliable chronological framework for the loess/palaeosol record from the Schwalbenberg section. A further aim is to test whether the multiple aliquot IRSL and TL results from the 1990s are still suitable for geochronological interpretations. Based on the chronological framework of this paper and further high-resolution proxy data the loess/palaeosol record is correlated with the Greenland ice core records in a further paper (SCHIRMER, 2000a,b, 2011).

\section{Geological Setting}

The Schwalbenberg section is an artificial cliff close to the town of Remagen in the Middle Rhine valley (Fig. 1).
An older outcrop (SCHIRMER 1990, 1991) was later named Schwalbenberg I, whereas Schwalbenberg II is an extended wall few meters behind the wall of Schwalbenberg I. Both sections exhibit $13.5 \mathrm{~m}$ loess deposits over a gravel of the Lower Middle Terrace that ends with a truncated interglacial luvisol. The loess record from the section at Schwalbenberg is exceptional owing to its excellent preservation of the Middle Weichselian record, designated to represent most parts of MIS 4 and 3. The section hosts most parts of the Keldach Formation (MIS 4) represented by the lower loess of the section, moreover an unusually complete Ahrgau Formation (MIS 3), represented by the tight loess-soil sequence of the section, and above parts of the Hesbaye and perhaps the Brabant Formations (MIS 2), represented by the upper loess of the section (SCHIRMER 1995, 2000a,b, 2002, 2010, 2011) (Fig. 4).

The high amount of intercalated interstadial soils is remarkable. The Ahrgau-Formation correlates with its soils excellently to the Greenland Ice Core record, especially the Greenland Interstadials 17 to 6 , as supported by its ac- 

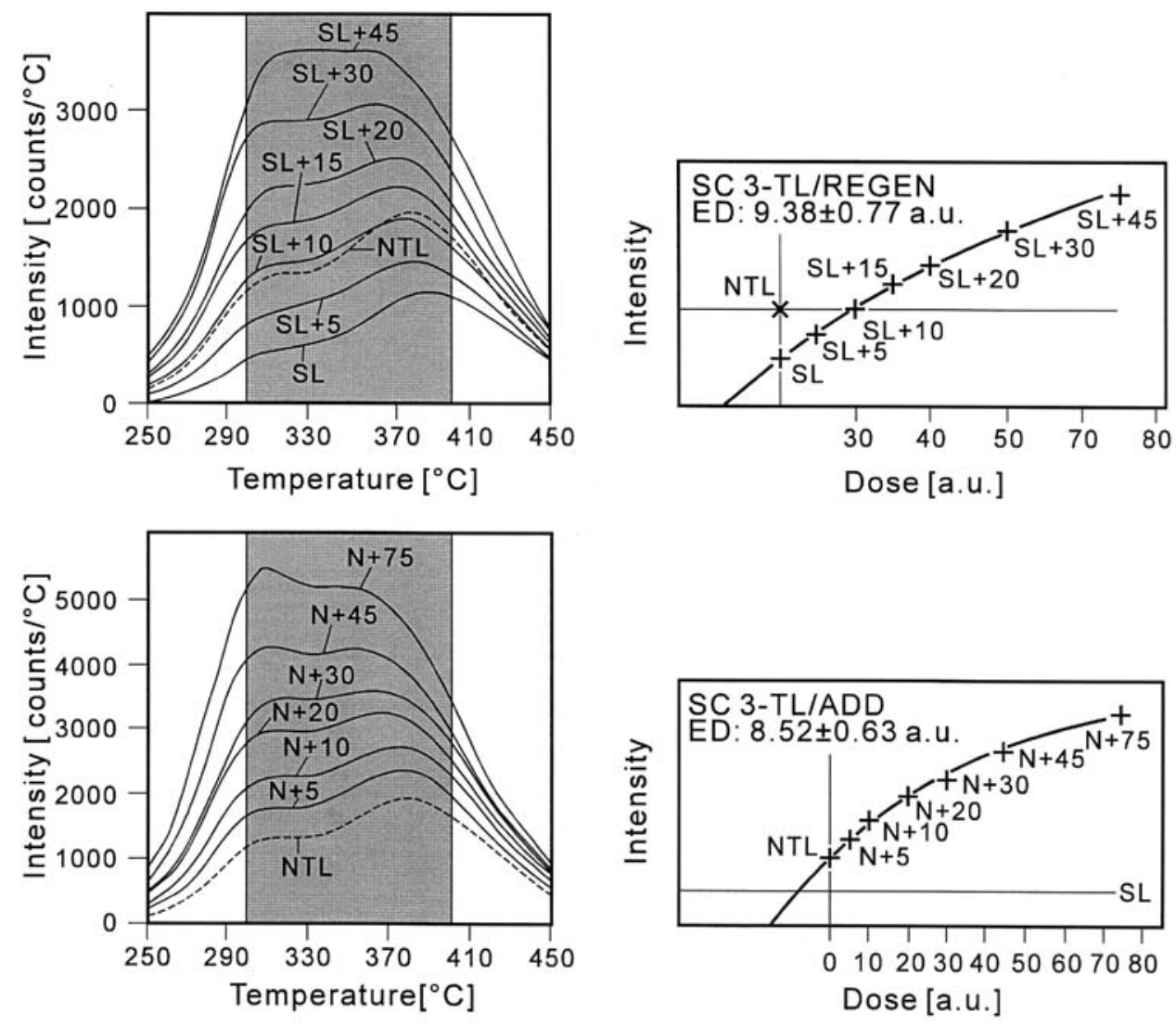

Fig. 2 (a): TL glow curves of sample Sc 3 and resulting growth curves, as determined by multiple aliquot protocols (regeneration and additive dose). Abb. 2 (a): TL-Glühkurven von Probe Sc 3 sowie die resultierenden Aufbaukurven (Regenerierung und Additive Dosis).
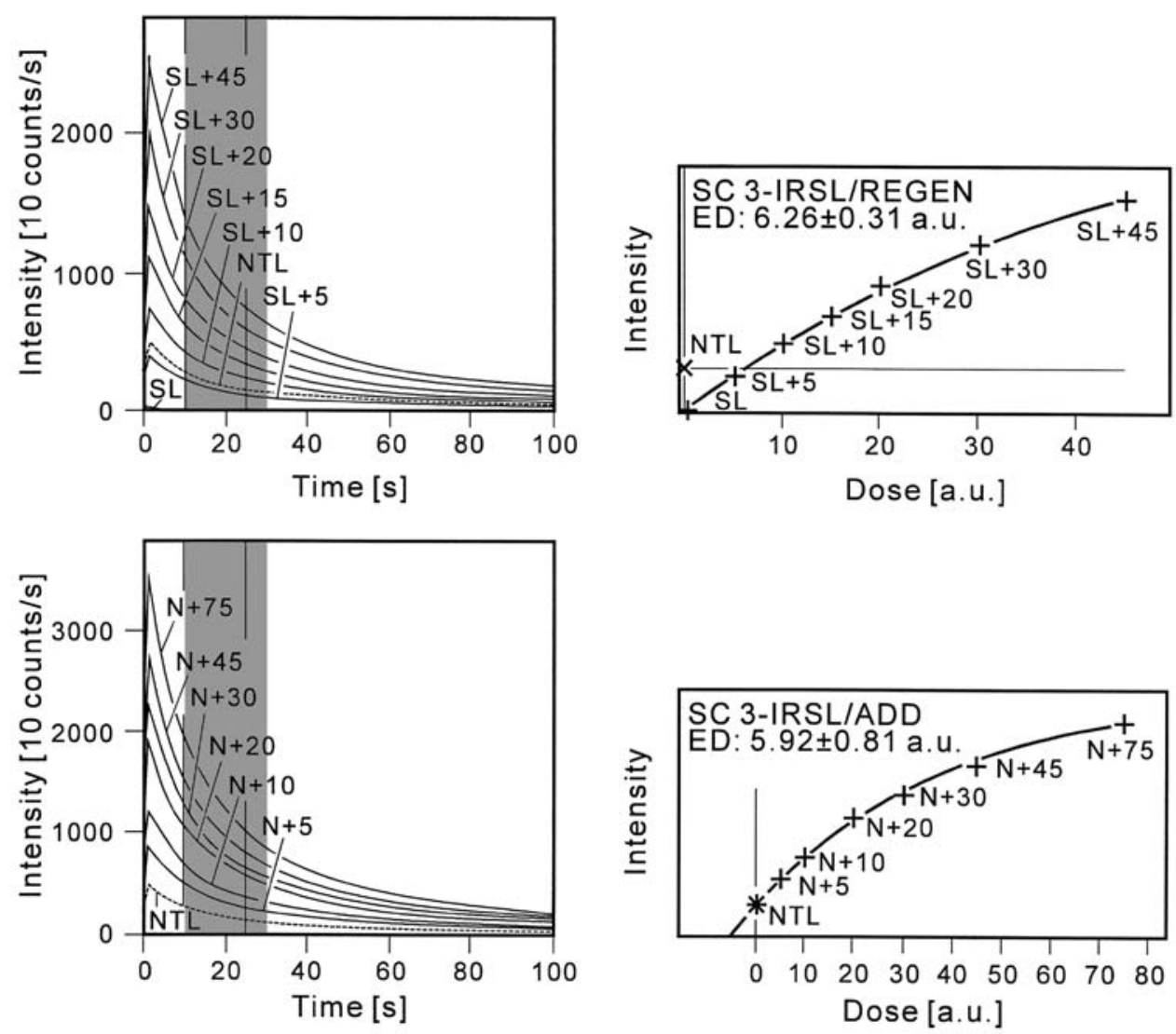

Fig. 2 (b): IRSL decay curves of sample Sc 3 and resulting growth curves, as determined by multiple aliquot protocols (regeneration and additive dose). Abb. 2 (b): IRSL-Ausleuchtkurven von Probe Sc 3 sowie die resultierenden Aufbaukurven (Regenerierung und Additive Dosis). 
count of soils, vertical distance of the soils, their rhythmic arrangement and their intensity indicated by the soil property curves. Thus, the Ahrgau Formation of the Schwalbenberg provides a good equivalent of the Greenland ice curves during MIS 3 (SCHIRmer 2000a, b, 2011). The Keldach Formation, represented by the lower loess, is from a lithostratigraphical point of view older than GIS 17, thus correlates to MIS 4. A detailed sedimentological/pedological description is given in SCHIRMER (2011).

\section{Luminescence dating}

Luminescence (including TL, OSL and IRSL) refers to the light emitted from crystals such as quartz, feldspar or zircon, when they are stimulated with heat or light after receiving a natural or artificial dose of radiation. As a result of natural radiation in sediments, the number of electrons migrating to traps that result from impurities and crystal defects, increases with time and dose. The equivalent dose $\left(D_{e}\right)$ is a measure of the past radiation absorbed and, in combination with the dose rate, yields the time passed since the last exposure to sunlight. Natural radiation results from the radioactive decay of isotopes in the decay chains of ${ }^{235} \mathrm{U}$, ${ }^{238} \mathrm{U},{ }^{232} \mathrm{Th}$, and the decay of ${ }^{40} \mathrm{~K}$, some minor isotopes including ${ }^{87} \mathrm{Rb}$, and cosmic rays. The luminescence age equals equivalent dose divided by dose rate. Further information about the methodological background is given by PreUSSER et al. (2008).

An important assumption for luminescence dating techniques is that the luminescence signals of the mineral grains have been bleached and reset to near zero by daylight prior to deposition. This assumption might be normally fulfilled for aeolian transport from the dust source, mainly floodplain of the Rhine Valley near the confluence of rivers Rhine and Ahr, and the area of deposition at the Schwalbenberg but might not necessarily be fulfilled for reworked loess, e.g. solifluction or slope wash. Unfortunately, thorough tests about the level of resetting of the signal and the application of statistical methods to determine the most likely deposition age have not yet been applied owing to the lack of appropriate methods in the application of polymineral finegrain material.

Previous studies have shown that luminescence signals from feldspar can suffer from anomalous fading (SPOONER 1994; WinTLE 1973), an unwanted loss of signal, which can result in age underestimation. Anomalous fading causes a decrease of the luminescence signal with time, faster than expected from thermal stability measurements. Fading corrections involve inherent assumptions including that the fading rate observed on a laboratory timescale is relevant to geological time (HunTLEY \& LAMOTHE, 2001), thus it is ideal to find a luminescence signal which shows negligible fading. Buylaert et al. (2009) applied an elevated temperature post-IR IRSL protocol proposed by ThомSEN et al. (2008) and could reduce the fading rate by a factor of two using the post-IR IRSL at $225^{\circ} \mathrm{C}$ compared to the IRSL signal at $50^{\circ} \mathrm{C}$. Their fading-corrected ages agreed well with ages derived from independent age control.

The reduced fading rate using post-IR IRSL signal was confirmed in several chronological studies about European loess (Thiel et al. 2011a, b).

\section{Experimental details}

\section{Multiple aliquot additive dose and regeneration dose protocol}

In this study all measurements were carried out on the 4-11 $\mu \mathrm{m}$ polymineral fine grain fraction, using the preparation technique described in FreCHEN (1994) and FRECHEN et al. (1997). The artificial irradiation for multiple aliquot protocols was performed using a Co-60 gamma source in Louvain-la-Neuve, Belgium, at the Institut Nucléaire et Chimie Inorganique. Bleaching was done using an UV lamp (Osram Ultra Vitalux 300W) for 16 hours to reset luminescence signals. The samples were stored at room temperature for at least four weeks between artificial irradiation and measurement. Furthermore, the samples were stored for at least 48 hours after preheating at $150^{\circ} \mathrm{C}$ for 16 hours on a heating plate in order to eliminate the unstable part of IRSL and TL signals and then measured. The signal emission, mainly from feldspar, was detected for all samples through a filter combination of Schott BG-39 and Chance Pilkington HA-3. After 25 seconds of IR stimulation at room temperature, the same discs were immediately heated to obtain their TL. The aliquots were measured with a heating rate of $5^{\circ} \mathrm{C} / \mathrm{s}$ up to $450^{\circ} \mathrm{C} . \mathrm{D}_{\mathrm{e}}$ values were obtained by integrating the $10-25 \mathrm{~s}$ regions of the IR decay curves and the $300-400^{\circ} \mathrm{C}$ regions of the TL glow curves. An exponential growth curve was fitted for the different dose steps and compared with the natural luminescence signals to estimate the equivalent dose. Examples for IR decay curves and TL glow curves and the growth curves are shown for sample SC 3 in Figure 2.

\section{Single aliquot regenerative-dose protocol [SAR]}

The development of SAR protocols was an important milestone improving accuracy and precision in luminescence dating of quartz, feldspar and polymineral fine-grains (MuRRAY \& WINTLE 2000; WALLINGA et al. 2000). The SAR protocol allows the determination of equivalent dose by interpolation with an about $5 \%$ precision. Sensitivity changes are monitored and corrected. Although anomalous fading has not been described as a significant problem for dating last glacial loess from the Rhineland, it can cause age underestimation. So far only samples from the Tönchesberg section situated in the Middle Rhine area have been investigated and cross-checked with both multiple aliquot (additive dose and regeneration) and SAR protocols for $\mathrm{D}_{\mathrm{e}}$ determination including fading correction (SCHMIDT et al. 2011). However, fading correction is problematic and a reliable procedure is still under discussion (HunTLEY \& LAMOTHE 2001). Based on the studies of Thomsen et al. (2008), Buylaert et al. (2009) proposed a modified SAR IRSL protocol which involves elevated temperature stimulation with IR for $100 \mathrm{~s}$ at $225^{\circ} \mathrm{C}$ following stimulation with IR at $50^{\circ} \mathrm{C}$ for $100 \mathrm{~s}$, so-called postIR IRSL measurement sequence. This protocol was successfully applied to penultimate and last glacial loess from the Middle Rhine area, Austria and Serbia (Schmidt et al. 2010, 2011; THIEL et al. 2011a, b). The latter studies have shown that the observed fading rates for the post-IR IRSL signal are significantly lower than those determined for the conventional IRSL at $50^{\circ} \mathrm{C}$. Furthermore, it was demonstrated that 
Tab. 1: Dosimetric results. Uranium, thorium and potassium content were determined by gammaspectrometry in the laboratory. Tab. 1: Dosimetrische Ergebnisse. Uran-, Thorium- und Kaliumgehalt wurden im Labor mittels Gammaspektrometrie bestimmt.

\begin{tabular}{|c|c|c|c|c|c|c|c|}
\hline Sample & $\begin{array}{l}\text { Uranium } \\
\text { [ppm] }\end{array}$ & $\begin{array}{l}\text { Thorium } \\
\text { [ppm] }\end{array}$ & $\begin{array}{l}\text { Potassium } \\
\text { [\%] }\end{array}$ & $\begin{array}{l}\text { a value } \\
\text { IRSL }\end{array}$ & $\begin{array}{l}\text { IR dose rate } \\
\text { [Gy/ka] }\end{array}$ & $\begin{array}{l}\text { a value } \\
\text { TL }\end{array}$ & $\begin{array}{l}\text { TL dose rate } \\
\text { [Gy/ka] }\end{array}$ \\
\hline SC1 & $2.90 \pm 0.20$ & $10.36 \pm 0.73$ & $1.59 \pm 0.11$ & 0.070 & $3.74 \pm 0.30$ & 0.090 & $3.99 \pm 0.33$ \\
\hline SC2 & $2.72 \pm 0.19$ & $10.06 \pm 0.70$ & $1.47 \pm 0.10$ & 0.075 & $3.60 \pm 0.29$ & 0.101 & $3.91 \pm 0.32$ \\
\hline SC3 & $2.72 \pm 0.19$ & $9.55 \pm 0.67$ & $1.40 \pm 0.10$ & 0.070 & $3.18 \pm 0.26$ & 0.090 & $3.39 \pm 0.29$ \\
\hline SC4 & $2.67 \pm 0.19$ & $9.93 \pm 0.70$ & $1.47 \pm 0.10$ & 0.065 & $3.44 \pm 0.27$ & 0.079 & $3.69 \pm 0.30$ \\
\hline SC5 & 2.88 \pm 0.20 & $10.42 \pm 0.73$ & $1.58 \pm 0.11$ & 0.065 & $3.67 \pm 0.29$ & 0.086 & $3.93 \pm 0.32$ \\
\hline SC6 & $2.72 \pm 0.19$ & $10.46 \pm 0.73$ & $1.59 \pm 0.11$ & 0.072 & $3.71 \pm 0.29$ & 0.085 & $3.87 \pm 0.31$ \\
\hline SC7 & $2.65 \pm 0.19$ & $10.00 \pm 0.70$ & $1.57 \pm 0.11$ & 0.077 & $3.67 \pm 0.30$ & 0.095 & $3.89 \pm 0.32$ \\
\hline SC8 & $2.76 \pm 0.19$ & $9.68 \pm 0.68$ & $1.56 \pm 0.11$ & 0.080 & $3.71 \pm 0.30$ & 0.103 & $3.98 \pm 0.33$ \\
\hline SC9 & $2.82 \pm 0.20$ & $9.81 \pm 0.69$ & $1.52 \pm 0.11$ & 0.068 & $3.56 \pm 0.29$ & 0.080 & $3.71 \pm 0.30$ \\
\hline SC10 & $2.83 \pm 0.20$ & $10.52 \pm 0.74$ & $1.59 \pm 0.11$ & 0.077 & $3.82 \pm 0.31$ & 0.098 & $4.08 \pm 0.34$ \\
\hline SC11 & $2.80 \pm 0.20$ & $10.13 \pm 0.71$ & $1.55 \pm 0.11$ & 0.080 & $3.77 \pm 0.31$ & 0.098 & $3.99 \pm 0.33$ \\
\hline SC12 & $2.27 \pm 0.16$ & $7.70 \pm 0.54$ & $1.09 \pm 0.06$ & 0.087 & $2.95 \pm 0.23$ & 0.118 & $3.24 \pm 0.27$ \\
\hline SC13 & $2.56 \pm 0.18$ & $8.76 \pm 0.61$ & $1.26 \pm 0.06$ & 0.073 & $3.18 \pm 0.24$ & 0.096 & $3.44 \pm 0.27$ \\
\hline SC14 & $2.67 \pm 0.19$ & $8.81 \pm 0.62$ & $1.26 \pm 0.06$ & 0.085 & $3.37 \pm 0.26$ & 0.095 & $3.48 \pm 0.28$ \\
\hline SC15 & $2.55 \pm 0.15$ & $8.72 \pm 0.61$ & $1.16 \pm 0.06$ & 0.074 & $3.10 \pm 0.24$ & 0.098 & $3.36 \pm 0.27$ \\
\hline SC16 & $2.64 \pm 0.18$ & $9.20 \pm 0.64$ & $1.25 \pm 0.06$ & 0.066 & $3.18 \pm 0.24$ & 0.076 & $3.29 \pm 0.25$ \\
\hline SC17 & $2.64 \pm 0.18$ & $8.97 \pm 0.63$ & $1.26 \pm 0.06$ & 0.078 & $3.29 \pm 0.25$ & 0.089 & $3.42 \pm 0.27$ \\
\hline SC18 & $2.46 \pm 0.17$ & $9.14 \pm 0.64$ & $1.21 \pm 0.06$ & 0.064 & $3.05 \pm 0.23$ & 0.068 & $3.09 \pm 0.24$ \\
\hline SC19 & $2.73 \pm 0.19$ & $9.45 \pm 0.66$ & $1.19 \pm 0.06$ & 0.065 & $3.17 \pm 0.24$ & 0.080 & $3.35 \pm 0.26$ \\
\hline SC20 & $2.64 \pm 0.18$ & $8.78 \pm 0.61$ & $1.16 \pm 0.06$ & 0.065 & $3.04 \pm 0.23$ & 0.099 & $3.42 \pm 0.27$ \\
\hline SC21 & $2.37 \pm 0.17$ & $7.87 \pm 0.55$ & $1.09 \pm 0.06$ & 0.066 & $2.80 \pm 0.21$ & 0.121 & $3.35 \pm 0.28$ \\
\hline SC22 & $2.47 \pm 0.17$ & $8.34 \pm 0.58$ & $1.11 \pm 0.06$ & 0.087 & $3.12 \pm 0.25$ & 0.098 & $3.24 \pm 0.26$ \\
\hline SC23 & $2.54 \pm 0.18$ & $8.54 \pm 0.60$ & $1.17 \pm 0.06$ & 0.093 & $3.29 \pm 0.26$ & 0.119 & $3.57 \pm 0.30$ \\
\hline SC24 & $2.43 \pm 0.17$ & $7.81 \pm 0.55$ & $1.03 \pm 0.05$ & 0.073 & $2.83 \pm 0.22$ & 0.106 & $3.16 \pm 0.26$ \\
\hline SC25 & $2.47 \pm 0.17$ & $8.36 \pm 0.59$ & $1.14 \pm 0.06$ & 0.061 & $2.88 \pm 0.22$ & 0.076 & $3.03 \pm 0.23$ \\
\hline SC26 & $2.10 \pm 0.15$ & $7.41 \pm 0.52$ & $0.95 \pm 0.05$ & 0.073 & $2.59 \pm 0.20$ & 0.099 & $2.83 \pm 0.23$ \\
\hline SC27 & $2.36 \pm 0.16$ & $7.86 \pm 0.55$ & $1.08 \pm 0.06$ & 0.064 & $2.76 \pm 0.21$ & 0.103 & $3.15 \pm 0.25$ \\
\hline SC28 & $2.31 \pm 0.16$ & $7.44 \pm 0.52$ & $0.99 \pm 0.05$ & 0.065 & $2.63 \pm 0.20$ & 0.099 & $2.96 \pm 0.24$ \\
\hline SC29 & $2.63 \pm 0.18$ & $8.75 \pm 0.61$ & $1.23 \pm 0.06$ & 0.065 & $3.10 \pm 0.23$ & 0.082 & $3.28 \pm 0.26$ \\
\hline SC30 & $2.52 \pm 0.18$ & $9.69 \pm 0.68$ & $1.33 \pm 0.07$ & 0.091 & $3.54 \pm 0.28$ & 0.105 & $3.70 \pm 0.30$ \\
\hline SC31 & $2.89 \pm 0.20$ & $9.95 \pm 0.70$ & $1.51 \pm 0.08$ & 0.063 & $3.61 \pm 0.29$ & 0.084 & $3.79 \pm 0.31$ \\
\hline SC32 & $2.88 \pm 0.20$ & $10.46 \pm 0.73$ & $1.55 \pm 0.08$ & 0.069 & $3.70 \pm 0.30$ & 0.075 & $3.77 \pm 0.31$ \\
\hline SC33 & $2.85 \pm 0.20$ & $10.50 \pm 0.74$ & $1.59 \pm 0.08$ & 0.071 & $3.75 \pm 0.30$ & 0.055 & $3.55 \pm 0.28$ \\
\hline SC34 & $2.90 \pm 0.20$ & $10.91 \pm 0.76$ & $1.62 \pm 0.08$ & 0.051 & $3.58 \pm 0.28$ & 0.055 & $3.63 \pm 0.29$ \\
\hline SC35 & $2.82 \pm 0.17$ & $10.43 \pm 0.63$ & $1.61 \pm 0.08$ & 0.050 & $3.48 \pm 0.26$ & 0.058 & $3.58 \pm 0.27$ \\
\hline SC36 & $2.96 \pm 0.21$ & $10.60 \pm 0.74$ & $1.59 \pm 0.08$ & 0.048 & $3.50 \pm 0.27$ & 0.058 & $3.63 \pm 0.29$ \\
\hline SC37 & $2.95 \pm 0.21$ & $10.06 \pm 0.70$ & $1.51 \pm 0.08$ & 0.055 & $3.47 \pm 0.28$ & 0.066 & $3.61 \pm 0.29$ \\
\hline SC38 & $2.67 \pm 0.19$ & $9.52 \pm 0.67$ & $1.38 \pm 0.07$ & 0.057 & $3.23 \pm 0.26$ & 0.072 & $3.40 \pm 0.27$ \\
\hline SC39 & $2.74 \pm 0.19$ & $9.29 \pm 0.65$ & $1.39 \pm 0.07$ & 0.072 & $3.41 \pm 0.27$ & 0.092 & $3.65 \pm 0.30$ \\
\hline SC40 & $3.12 \pm 0.22$ & $10.66 \pm 0.75$ & $1.39 \pm 0.07$ & 0.078 & $3.79 \pm 0.31$ & 0.092 & $3.97 \pm 0.33$ \\
\hline SC41 & $3.11 \pm 0.18$ & $10.21 \pm 0.61$ & $1.34 \pm 0.07$ & 0.079 & $3.70 \pm 0.29$ & 0.095 & $3.91 \pm 0.32$ \\
\hline sc42 & $3.33 \pm 0.23$ & $10.96 \pm 0.77$ & $1.39 \pm 0.07$ & 0.081 & $3.94 \pm 0.32$ & 0.098 & $4.18 \pm 0.35$ \\
\hline SC43 & $3.12 \pm 0.22$ & $10.31 \pm 0.72$ & $1.33 \pm 0.07$ & 0.091 & $3.87 \pm 0.32$ & 0.119 & $4.23 \pm 0.36$ \\
\hline SC44 & $2.85 \pm 0.20$ & $9.42 \pm 0.66$ & $1.37 \pm 0.10$ & 0.085 & $3.61 \pm 0.30$ & 0.105 & $3.85 \pm 0.32$ \\
\hline
\end{tabular}


the post-IR IRSL at $225^{\circ} \mathrm{C}$ is bleachable by natural daylight/ sunlight (BuylaERT et al., 2009). Therefore, this approach was further tested in this study for loess and loess derivatives from the Schwalbenberg section. Optically stimulated luminescence (OSL) of fine-grain $(4-11 \mu \mathrm{m})$ quartz has also been widely used to estimate the deposition age of sediments (Schmid et al. 2011 and references therein) and is usually regarded as an accurate and precise dating method. However, the fast component of the quartz OSL, which is usually used for dating, saturates at doses between 200 and 400 Gy. Reliable quartz OSL age estimates were obtained for loess from the Middle Rhine area up to about $70 \mathrm{ka}$ (SchmidT et al. 2011) and were in excellent agreement with post-IR IRSL results.

Polymineral fine-grain material was taken from four samples for applying SAR protocols to determine the $\mathrm{D}_{\mathrm{e}}$ values and the g-values to calculate the fading-corrected IRSL age estimates. $D_{e}$ measurements for all SAR protocols were performed with an automated Risö reader TL/OSL-DA-15 equipped with a ${ }^{90} \mathrm{Sr} /{ }^{90} \mathrm{Y}$ beta source at the Leibniz Institute for Applied Geophysics (LIAG) in Hannover. A Schott BG 39 and a Corning 7-59 filter combination passing the blue wavelength spectra between 320 and $460 \mathrm{~nm}$ were intercalated between samples and photomultiplier for measurements including IRSL at $50^{\circ} \mathrm{C}$ and post-IR IRSL at $225^{\circ} \mathrm{C}$. The polymineral fine-grains were bleached after preheat at $250^{\circ} \mathrm{C}$ for 60 $\mathrm{s}$ with IR diodes at $50^{\circ} \mathrm{C}$ for $100 \mathrm{~s}$ and subsequently luminescence-measured at $225^{\circ} \mathrm{C}$ for $100 \mathrm{~s}$. Within the applied postIR IRSL protocol the standard IRSL signal at $50^{\circ} \mathrm{C}$ was also recorded. Thus it is possible to compare both the $\mathrm{D}_{\mathrm{e}}$ values and the fading rates for IR at $50^{\circ} \mathrm{C}$ and post-IR IRSL at $225^{\circ} \mathrm{C}$. Performance tests were adopted to test the reliability of SAR protocols, e.g. dose recovery test and the determination of residuals, as shown in Table 3.

Aliquots three each were bleached from four samples for four hours by a dr hönle SOL2 solar simulator and then the apparent dose was measured in the usual manner. The residual dose values range from $1.79 \pm 0.13$ Gy to $1.84 \pm 0.13 \mathrm{~Gy}$ and from $4.75 \pm 0.33$ to $6.40 \pm 0.39$ Gy for IRSL at $50^{\circ} \mathrm{C}$ and for post-IR IRSL at $225^{\circ} \mathrm{C}$, respectively. The $S A R D_{e}$ results are shown in Table 3.

Dose recovery ratios were measured for four samples using the IRSL at $50^{\circ} \mathrm{C}$ and the post-IR IRSL at $225^{\circ} \mathrm{C}$. Aliquots were first bleached in a dr hönle SOL 2 solar simulator for four hours and then a dose of 100 Gy was given, which is approximately equal to their natural dose. The dose recovery tests are between 0.89 and 0.99 and between 0.91 and 0.98 , respectively. Dose recovery tests after subtracting residuals yield values ranging from 0.88 to 0.97 and from 0.85 to 0.93 for IRSL at $50^{\circ} \mathrm{C}$ and for post-IR IRSL at $225^{\circ} \mathrm{C}$, respectively. Table 4 shows the individual dose recovery ratios for all aliquots. All dose response curves, for both IRSL at $50^{\circ} \mathrm{C}$ and post-IR IRSL at $225^{\circ} \mathrm{C}$, were fitted using an exponential function.

\section{Laboratory fading}

No fading rates are available for the multiple aliquot approach. To minimize fading, the samples were stored for at least four weeks between irradiation and measurements. Furthermore, the 10-25s integral of the IR decay curves was taken for IRSL $\mathrm{D}_{\mathrm{e}}$ determination; this part of the decay curve was found to show less fading than the initial part, e.g. the integral $0-1$ s. The laboratory fading rates were measured as an IRSL signal decrease over time on artificially irradiated aliquots. The same aliquots used for $\mathrm{D}_{\mathrm{e}}$ measurements were used for fading measurements, six per sample; the aliquots were bleached and a dose of 100 Gy was given. The preheat was applied immediately after irradiation and before storage. After storage ranging from repeated prompt measurements to delays up to 65 hours, the aliquots were measured. Fading rates for the IRSL signal at $50^{\circ} \mathrm{C}$ range from 1.6 to $2.5 \%$ /decade, whereas for the post-IR IRSL signal at $225^{\circ} \mathrm{C}$ the fading rates are reduced ranging from 0.3 to $0.8 \% /$ decade. The less fading of the post-IR IRSL signal indicates that the post-IR IRSL signal at $225^{\circ} \mathrm{C}$ is more stable than the standard IRSL signal at $50^{\circ} \mathrm{C}$. Following the suggestions of Thomsen et al. (2008) fading correction was not applied for g-values smaller than $1 \% /$ decade.

\section{Dosimetry}

Dose-rates for all samples were obtained from potassium, uranium and thorium content, as measured by gamma spectrometry in the laboratory (Geological Institute, University of Cologne), assuming a radioactive equilibrium for the sediments (Table 1). The measured in situ water content for section Schwalbenberg II was below 5\% owing to decades of exposure. Therefore a water content of $15 \pm 5 \%$ was estimated for all samples. Alpha irradiation was carried out at the same institute with a ${ }^{241} \mathrm{Am}$ source for all samples to determine alpha efficiency (a value) (Table 1).

\section{Results}

The uranium, thorium and potassium content and total dose rates are shown in Table 1. The mean dose rate is 3.37 Gy/ka and 3.58 Gy/ka for IRSL and TL, respectively, ranging from $2.59 \mathrm{~Gy} / \mathrm{ka}$ to $4.23 \mathrm{~Gy} / \mathrm{ka}$ for all dose rates.

$\mathrm{D}_{\mathrm{e}}$ values, as determined by MA regeneration and additive dose protocols, range from 61.8 to 196.4 Gray (Gy) and from 82.2 to 252.3 Gy for IRSL and TL, respectively. The mean IRSL/TL $\mathrm{D}_{\mathrm{e}}$ ratio is 0.74 and 0.77 for the MA regeneration and additive dose protocol, respectively, indicating a significant average IRSL underestimation or TL overestimation very likely owing to insufficient bleaching prior to deposition (Fig. 3).

Four main IRSL age cluster can be distinguished for the loess/palaeosol sequence at the Schwalbenberg II section.

a. Lower Pleniglacial / early Middle Weichselian: IRSL age estimates between 55 and $45 \mathrm{ka}$

b. Early Middle Pleniglacial / middle Middle Weichselian: IRSL age estimates around $40 \mathrm{ka}$

c. Late Middle Pleniglacial/ late Middle Weichselian: IRSL age estimates between 35 and $25 \mathrm{ka}$

d. Upper Weichselian: between 25 and $18 \mathrm{ka}$

Samples SC 1-15 were taken from the lowermost $4 \mathrm{~m}$ of the profile, below the discontinuity at $4.0 \mathrm{~m}$ (Fig. 4 and 5). IRSL age estimates, as determined by the MA regeneration and additive dose protocol, range from $50.9 \pm 4.3 \mathrm{ka}$ to $38.4 \pm 3.5$ $\mathrm{ka}$ and from $50.3 \pm 4.3 \mathrm{ka}$ to $37.7 \pm 4.2 \mathrm{ka}$, respectively. TL age 


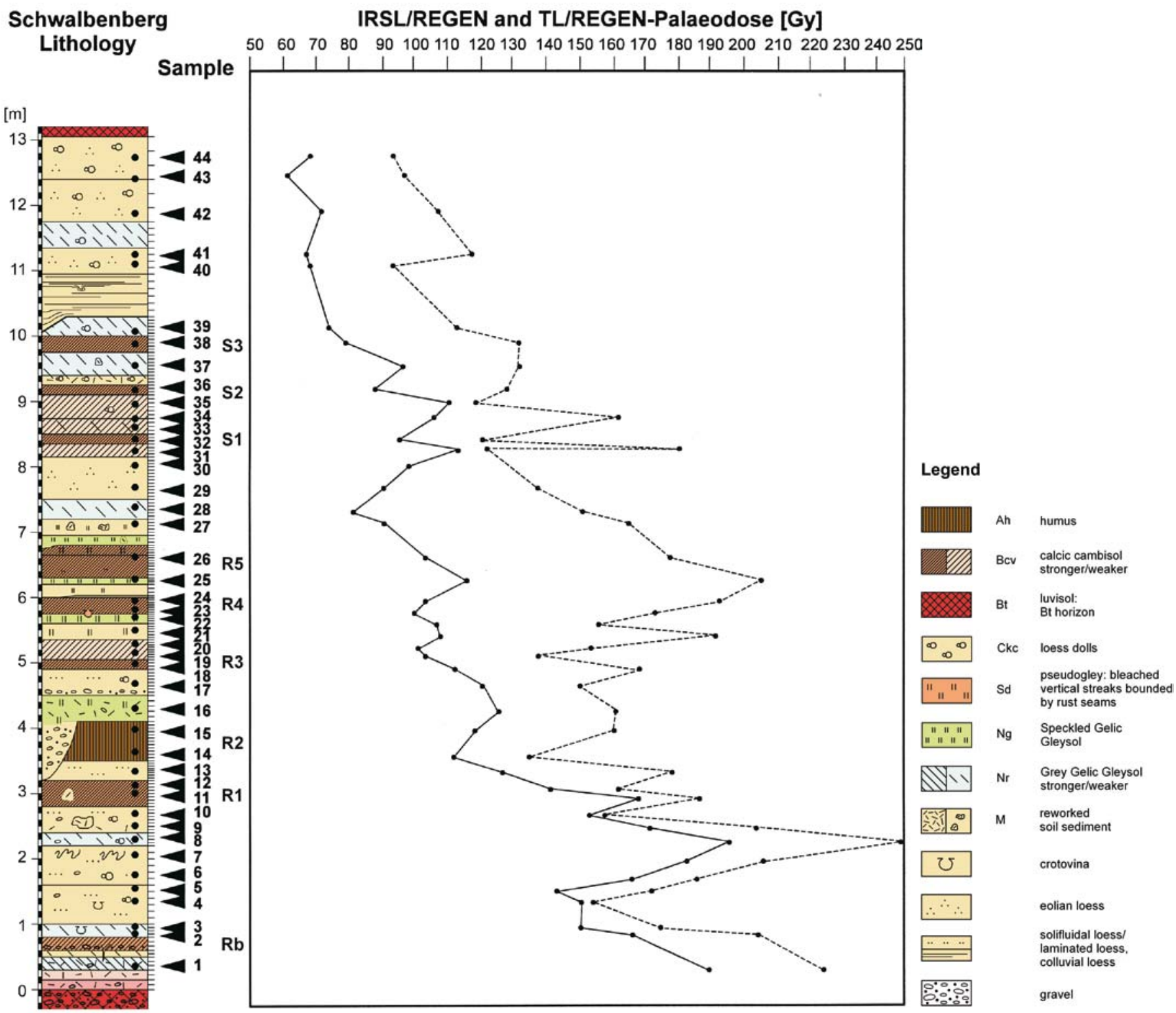

Fig. 3: Comparison of $D_{e}$ values, as determined by IRSL and TL applying the multiple aliquot approach. $R b=$ Reisberg Soil, $R 1-5=$ Remagen Soils 1-5, S 1-3 = Sinzig Soils 1-3.

Abb. 3: Vergleich von $D_{e}$-Werten mittels IRSL und TL im Multiple Aliquot Protokoll bestimmt. Rb $=$ Reisberg-Boden, $R 1-5=$ Remagen-Böden 1-5,

S1-3 = Sinzig-Böden 1-3.

estimates have a slightly higher mean age but are in agreement within the 1-sigma standard deviation with the IRSL age estimates for most of the samples (Table 2). The TL results show a larger sample to sample scatter of $\mathrm{D}_{\mathrm{e}}$ values, very likely owing to incomplete bleaching, as TL needs more daylight exposure time for complete resetting than IRSL.

Fading-corrected IRSL or TL age estimates are not available for the subsamples measured by multiple aliquot protocols. In order to minimize fading for aliquots measured by MA, samples were stored for at least four weeks after irradiation and prior to the measurement. Furthermore, the middle part of the IR decay curves was integrated, which is known to be the part of the IRSL decay curve showing less fading than the initial part of the curve. In order to test the reliability of the applied MA protocols, which were commonly applied in the 1990s (e.g. FreCHEN 1994; FreChen et al.1995; ZÖLLER et al.1991) for samples from the Middle Rhine area, single aliquot regenerative protocols were ap- plied using post-IR IRSL at $225^{\circ} \mathrm{C}$ and IRSL at $50^{\circ} \mathrm{C}$ including fading correction. Sample Sc 11 was chosen for comparison. The IRSL age estimates for IRSL at $50^{\circ} \mathrm{C}$ and post-IR IRSL at $225^{\circ} \mathrm{C}$ are $53.9 \pm 4.8 \mathrm{ka}$ and $57.0 \pm 4.7 \mathrm{ka}$, respectively. The latter mean IRSL age estimates are about $20 \%$ higher than those determined by MA protocols but are in agreement within the 1-sigma standard deviation and hence do not alter the chronostratigraphic interpretation significantly.

Samples Sc 16-26 were taken between $4.00 \mathrm{~m}$ and $7.20 \mathrm{~m}$. IRSL age estimates range from $39.7 \pm 3.6 \mathrm{ka}$ and $40.4 \pm 4.4 \mathrm{ka}$ (MA regeneration) and from $37.5 \pm 5.4 \mathrm{ka}$ to $41.3 \pm 3.7 \mathrm{ka}$ (MA additive dose) whereas TL age estimates are between $48.3 \pm 4.6$ $\mathrm{ka}$ and $63.5 \pm 7.3 \mathrm{ka}$ (MA regeneration) and between $46.8 \pm 4.3$ $\mathrm{ka}$ and $35.0 \pm 3.9 \mathrm{ka}$ (MA additive dose). TL results show a larger $D_{e}$ and age scatter most likely caused by incomplete bleaching. Neither IRSL age estimates nor TL age estimates show age increase for this part of the sequence Samples Sc 27-39 were taken between $7.20 \mathrm{~m}$ and $9.80 \mathrm{~m}$. IRSL age es- 
Table 2: $D_{e}$ values, as determined by multiple aliquot protocols (additive dose and regeneration) and IRSL and TL age estimates. A delay between irradiation and measurement of at least four weeks and the late decay curve integral (10-25s) was taken for IRSL $D_{e}$ determination to minimize fading. However, fading-correction was not applied for these samples.

Tabelle 2: $D_{e}$-Werte mittels Multiple Aliquot Protokoll (additive Methode und Regenerierungsmethode) sowie IRSL- und TL-Alter. Zwischen Bestrahlung und Messung der Proben wurde mindestens vier Wochen gewartet und der hintere Teil der IR-Zerfallskurve wurde für die $D_{e}$-Bestimmung integriert, um so eventuell vorkommendes Fading zu minimieren. Eine Fading-Korrektur wurde nicht durchgeführt.

\begin{tabular}{|c|c|c|c|c|c|c|c|c|}
\hline Sample & IRSL/REGEN & IRSL/ADD & TL/REGEN & TL/ADD & IRSL/REGEN & IRSL/ADD & TL/REGEN & TL/ADD \\
\hline \multicolumn{5}{|c|}{ Equlvalent dose in Gray [Gy] } & \multicolumn{4}{|c|}{ Age in 1000 years [ka] } \\
\hline SC1 & $190.2 \pm 5.4$ & $188.1 \pm 6.1$ & $224.6 \pm 20.2$ & $189.6 \pm 2.3$ & $50.9 \pm 4.3$ & $50.3 \pm 4.3$ & $56.3 \pm 6.8$ & $47.5 \pm 3.9$ \\
\hline SC2 & $167.2 \pm 8.5$ & $158.1 \pm 44.9$ & $205.2 \pm 14.1$ & $190.1 \pm 16.8$ & $46.5 \pm 4.4$ & $44.0 \pm 13.0$ & $52.5 \pm 5.7$ & $48.6 \pm 5.9$ \\
\hline SC3 & $151.1 \pm 9.4$ & $134.6 \pm 5.9$ & $175.7 \pm 12.3$ & $164.1 \pm 2.9$ & $47.6 \pm 4.9$ & $42.4 \pm 4.0$ & $51.8 \pm 5.7$ & $48.4 \pm 4.2$ \\
\hline SC4 & $151.5 \pm 8.8$ & $182.7 \pm 10.3$ & $155.0 \pm 8.8$ & $199.7 \pm 11.9$ & $44.0 \pm 4.3$ & $53.1 \pm 5.2$ & $42.0 \pm 4.2$ & $54.1 \pm 5.5$ \\
\hline SC5 & $144.1 \pm 10.4$ & $151.8 \pm 10.9$ & $173.5 \pm 9.4$ & $184.3 \pm 9.3$ & $39.3 \pm 4.2$ & $41.4 \pm 4.4$ & $44.1 \pm 4.3$ & $46.9 \pm 4.5$ \\
\hline SC6 & $166.6 \pm 8.6$ & $176.5 \pm 16.4$ & $186.3 \pm 8.7$ & $190.8 \pm 9.2$ & $44.9 \pm 4.2$ & $47.6 \pm 5.8$ & $48.2 \pm 4.5$ & $49.3 \pm 4.6$ \\
\hline SC7 & $183.7 \pm 9.1$ & $181.2 \pm 22.6$ & $207.2 \pm 8.0$ & $208.3 \pm 17.5$ & $50.0 \pm 4.7$ & $49.3 \pm 7.3$ & $53.3 \pm 4.8$ & $53.6 \pm 6.3$ \\
\hline SC8 & $196.4 \pm 13.1$ & $165.8 \pm 26.1$ & $252.3 \pm 12.4$ & $179.1 \pm 20.7$ & $53.0 \pm 5.6$ & $44.7 \pm 7.9$ & $63.4 \pm 6.1$ & $45.0 \pm 6.4$ \\
\hline SC9 & $171.9 \pm 16.2$ & $181.1 \pm 18.3$ & $204.9 \pm 20.9$ & $204.1 \pm 10.1$ & $48.2 \pm 6.0$ & $50.8 \pm 6.6$ & $55.2 \pm 7.2$ & $55.0 \pm 5.2$ \\
\hline SC10 & $154.0 \pm 11.3$ & $156.3 \pm 3.1$ & $158.3 \pm 16.3$ & $160.2 \pm 5.7$ & $40.3 \pm 4.4$ & $40.9 \pm 3.4$ & $38.8 \pm 5.1$ & $39.2 \pm 3.5$ \\
\hline SC11 & $168.9 \pm 2.2$ & $172.7 \pm 25.8$ & $187.8 \pm 19.1$ & $173.9 \pm 3.6$ & $44.9 \pm 3.7$ & $45.9 \pm 7.8$ & $47.1 \pm 6.2$ & $43.6 \pm 3.7$ \\
\hline SC12 & $141.9 \pm 9.7$ & $149.5 \pm 19.6$ & $163.3 \pm 10.3$ & $220.6 \pm 9.5$ & $48.2 \pm 5.0$ & $50.8 \pm 7.7$ & $50.3 \pm 5.2$ & $68.0 \pm 6.3$ \\
\hline SC13 & $127.3 \pm 11.0$ & $122.8 \pm 11.7$ & $178.9 \pm 20.3$ & $167.2 \pm 6.3$ & $40.0 \pm 4.6$ & $38.6 \pm 4.7$ & $52.1 \pm 7.2$ & $48.7 \pm 4.3$ \\
\hline SC14 & $112.8 \pm 10.2$ & $99.5 \pm 13.0$ & $136.2 \pm 13.0$ & $128.2 \pm 7.6$ & $33.5 \pm 4.0$ & $29.6 \pm 4.5$ & $39.2 \pm 4.9$ & $36.9 \pm 3.7$ \\
\hline SC15 & $119.1 \pm 6.2$ & $116.9 \pm 9.3$ & $162.3 \pm 8.4$ & $157.4 \pm 7.2$ & $38.4 \pm 3.5$ & $37.7 \pm 4.2$ & $48.3 \pm 4.6$ & $46.8 \pm 4.3$ \\
\hline SC16 & $125.9 \pm 6.1$ & $118.9 \pm 14.4$ & $161.9 \pm 8.8$ & $180.7 \pm 3.9$ & $39.7 \pm 3.6$ & $37.5 \pm 5.4$ & $49.2 \pm 4.6$ & $54.9 \pm 4.4$ \\
\hline SC17 & $121.9 \pm 7.9$ & $127.3 \pm 10.5$ & $150.5 \pm 11.2$ & $163.3 \pm 5.2$ & $37.0 \pm 3.7$ & $38.6 \pm 4.4$ & $44.0 \pm 4.8$ & $47.8 \pm 4.1$ \\
\hline SC18 & $113.1 \pm 8.5$ & & & $169.5 \pm 12.0$ & & $37.1 \pm 4.0$ & & $54.9 \pm 5.7$ \\
\hline SC19 & $104.0 \pm 8.0$ & $90.6 \pm 11.2$ & $138.4 \pm 12.0$ & $120.6 \pm 6.7$ & $32.8 \pm 3.6$ & $28.6 \pm 4.2$ & $41.4 \pm 4.8$ & $36.0 \pm 3.5$ \\
\hline SC20 & $101.9 \pm 14.3$ & & & $154.5 \pm 21.6$ & & $33.5 \pm 5.3$ & & $45.2 \pm 7.3$ \\
\hline SC21 & $108.1 \pm 5.5$ & $115.4 \pm 5.8$ & $191.0 \pm 20.0$ & $201.0 \pm 10.5$ & $38.7 \pm 3.5$ & $41.3 \pm 3.7$ & $57.1 \pm 7.6$ & $60.1 \pm 5.9$ \\
\hline SC22 & $107.8 \pm 12.3$ & $104.9 \pm 10.0$ & $156.4 \pm 25.7$ & $147.4 \pm 10.7$ & $34.5 \pm 4.8$ & $33.6 \pm 4.2$ & $48.3 \pm 8.8$ & $45.6 \pm 4.9$ \\
\hline SC23 & $100.0 \pm 5.4$ & $80.9 \pm 7.2$ & $174.0 \pm 20.0$ & $124.8 \pm 9.3$ & $30.4 \pm 2.9$ & $24.6 \pm 2.9$ & $48.7 \pm 6.9$ & $35.0 \pm 3.9$ \\
\hline SC24 & $103.5 \pm 10.8$ & & & $192.8 \pm 23.5$ & & $36.6 \pm 4.7$ & & $61.0 \pm 8.9$ \\
\hline SC25 & $116.1 \pm 6.1$ & & & $205.8 \pm 9.1$ & & $40.4 \pm 3.7$ & & $67.9 \pm 6.0$ \\
\hline SC26 & $104.7 \pm 8.2$ & & & $179.7 \pm 14.9$ & & $40.4 \pm 4.4$ & & $63.5 \pm 7.3$ \\
\hline SC27 & $91.3 \pm 6.4$ & $81.3 \pm 7.4$ & $165.5 \pm 28.1$ & $136.5 \pm 13.1$ & $33.0 \pm 3.4$ & $29.4 \pm 3.5$ & $52.5 \pm 9.9$ & $43.3 \pm 5.4$ \\
\hline SC28 & $81.8 \pm 7.5$ & $72.1 \pm 13.6$ & $151.8 \pm 12.1$ & $116.9 \pm 9.2$ & $31.1 \pm 3.7$ & $27.4 \pm 5.6$ & $51.3 \pm 5.8$ & $39.5 \pm 4.4$ \\
\hline SC29 & $90.8 \pm 5.5$ & $92.6 \pm 11.5$ & $137.3 \pm 13.1$ & $148.7 \pm 10.0$ & $29.3+2.8$ & $29.9 \pm 4.4$ & $41.8 \pm 5.1$ & $45.3 \pm 4.7$ \\
\hline SC30 & $98.5 \pm 4.8$ & $102.5 \pm 6.9$ & $113.4 \pm 8.8$ & $117.6 \pm 6.6$ & $27.8 \pm 2.6$ & $29.0 \pm 3.0$ & $30.7 \pm 3.4$ & $31.8 \pm 3.1$ \\
\hline SC31 & $122.5 \pm 11.7$ & $115.5 \pm 27.7$ & $180.4 \pm 15.1$ & $192.1 \pm 15.7$ & $33.9 \pm 4.2$ & $32.0 \pm 8.1$ & $47.5 \pm 5.6$ & $50.6 \pm 5.9$ \\
\hline SC32 & $95.8 \pm 4.4$ & $100.4 \pm 6.0$ & $120.7 \pm 6.0$ & $128.9 \pm 2.9$ & $25.9 \pm 2.4$ & $27.2 \pm 2.7$ & $32.0 \pm 3.0$ & $34.2 \pm 2.9$ \\
\hline SC33 & $67.1 \pm 3.6$ & $67.7 \pm 3.2$ & $43.9 \pm 5.7$ & & & & & \\
\hline SC34 & $106.6 \pm 9.9$ & $90.9 \pm 3.0$ & $161.5 \pm 13.4$ & $144.2 \pm 7.2$ & $29.8 \pm 3.6$ & $25.4 \pm 2.2$ & $44.5 \pm 5.1$ & $39.7 \pm 3.7$ \\
\hline SC35 & $111.8 \pm 4.1$ & $98.1 \pm 5.7$ & $119.6 \pm 11.0$ & $112.5 \pm 3.8$ & $32.1 \pm 2.7$ & $28.2 \pm 2.7$ & $33.4 \pm 4.0$ & $31.4 \pm 2.6$ \\
\hline SC36 & $87.7 \pm 5.8$ & $90.9 \pm 21.5$ & $128.1 \pm 10.2$ & $127.8 \pm 7.8$ & $25.0 \pm 2.6$ & $26.0 \pm 6.5$ & $35.3 \pm 4.0$ & $35.2 \pm 3.5$ \\
\hline SC37 & $96.4 \pm 4.4$ & $93.8 \pm 11.7$ & $132.4 \pm 13.3$ & $112.2 \pm 2.3$ & $27.8 \pm 2.5$ & $27.1 \pm 4.0$ & $36.7 \pm 4.7$ & $31.1 \pm 2.6$ \\
\hline SC38 & $79.5 \pm 3.6$ & $77.6 \pm 6.8$ & $132.2 \pm 6.3$ & $116.4 \pm 3.9$ & $24.6 \pm 2.2$ & $24.0 \pm 2.8$ & $38.9 \pm 3.6$ & $34.2 \pm 3.0$ \\
\hline SC39 & $74.2 \pm 1.7$ & & & $113.2 \pm 10.6$ & & $21.7 \pm 1.8$ & & $31.1 \pm 3.9$ \\
\hline SC40 & $68.5 \pm 5.4$ & $68.3 \pm 5.9$ & $93.3 \pm 19.9$ & $87.9 \pm 4.1$ & $18.1 \pm 2.1$ & $18.0 \pm 2.1$ & $23.5 \pm 5.4$ & $22.1 \pm 2.1$ \\
\hline SC41 & $67.6 \pm 4.7$ & $64.5 \pm 13.8$ & $118.9 \pm 14.8$ & $114.4 \pm 10.8$ & $18.3 \pm 1.9$ & $17.4 \pm 4.0$ & $30.4 \pm 4.5$ & $29.3 \pm 3.6$ \\
\hline SC42 & $71.9 \pm 3.6$ & $68.0 \pm 9.3$ & $107.8 \pm 8.8$ & $97.9 \pm 7.2$ & $18.2 \pm 1.8$ & $17.2 \pm 2.8$ & $25.8 \pm 3.0$ & $23.4 \pm 2.6$ \\
\hline SC43 & $61.8 \pm 12.7$ & & & $97.2 \pm 17.9$ & & $16.0 \pm 3.5$ & & $23.0 \pm 4.7$ \\
\hline SC44 & $68.7 \pm 3.5$ & $68.2 \pm 5.5$ & $94.1 \pm 7.3$ & 82.2ะ2.3 & $19.0 \pm 1.8$ & $18.9 \pm 2.2$ & $24.5 \pm 2.8$ & $21.4 \pm 1.9$ \\
\hline
\end{tabular}




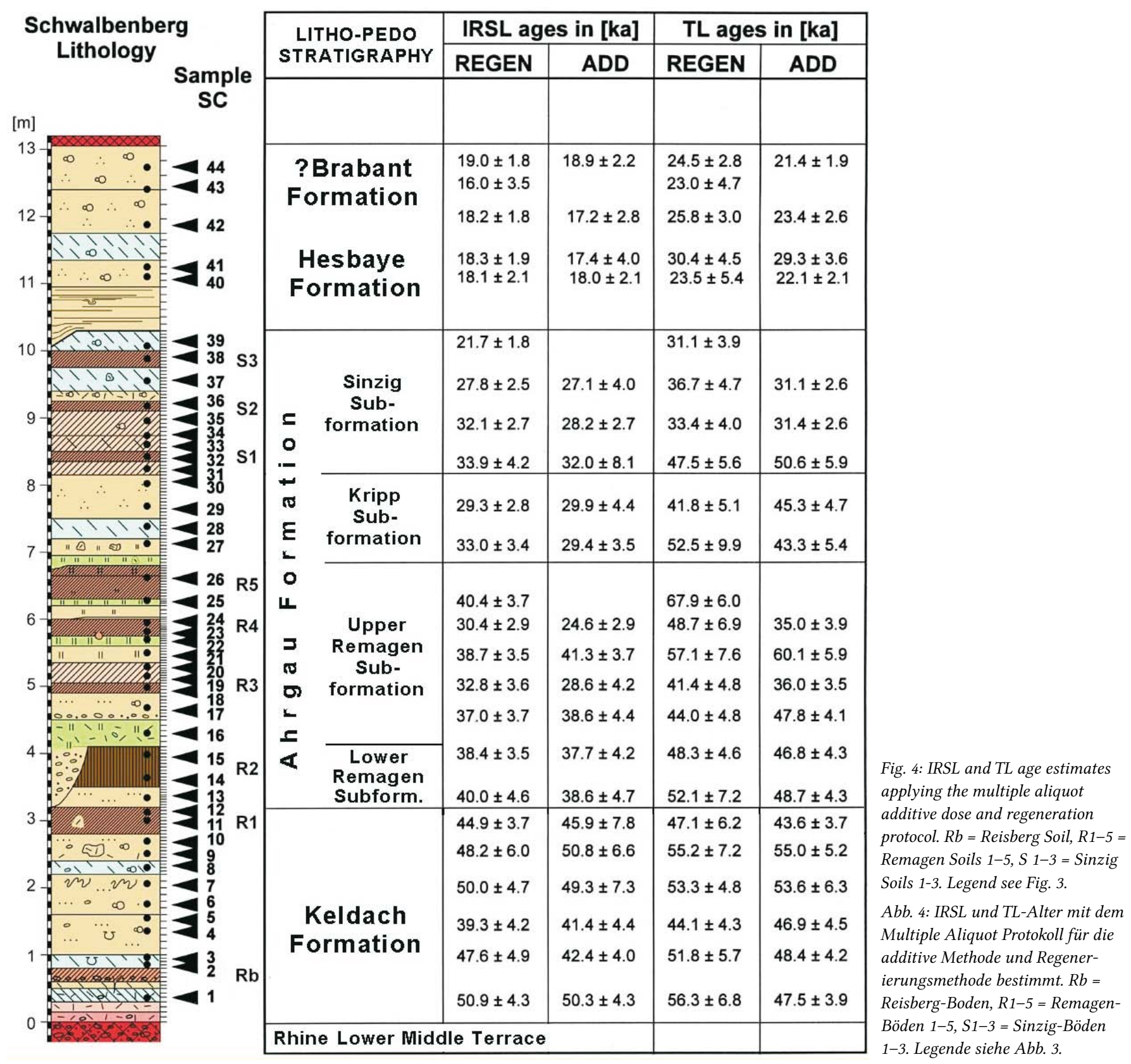

timates range from $33.0 \pm 3.4 \mathrm{ka}$ and $21.7 \pm 1.8 \mathrm{ka}$ and from $29.4 \pm 3.5 \mathrm{ka}$ and $24.0 \pm 2.8 \mathrm{ka}$, as determined by MA regeneration and additive dose protocols, respectively. TL age estimates are between $52.5 \pm 9.9 \mathrm{ka}$ and $31.1 \pm 3.9 \mathrm{ka}$ (MA regeneration) and between $43.3 \pm 5.4 \mathrm{ka}$ and $34.2 \pm 3.0 \mathrm{ka}$ (MA additive dose). The mean IRSL and TL values show a slight age increase with depth, whereas most of the single IRSL and TL age estimates are in agreement within the 1-sigma standard deviation.

Samples Sc 29 and Sc 35 were chosen for further investigation. Sample Sc 29 yielded IRSL age estimates for IRSL at $50^{\circ} \mathrm{C}$ and post-IR IRSL at $225^{\circ} \mathrm{C}$ of $30.3 \pm 2.7 \mathrm{ka}$ and $30.6 \pm 2.6$ $\mathrm{ka}$, respectively. MA protocols and fading-corrected ages, as determined by SAR protocols for IRSL at $50^{\circ} \mathrm{C}$ and postIR IRSL at $225^{\circ} \mathrm{C}$, are in agreement within the 1-sigma standard deviation. A significant age underestimation for the MA IRSL and MA TL age estimates was not found for this sample. Sample Sc 35 yielded age estimates for IRSL at $50^{\circ} \mathrm{C}$ and post-IR IRSL at $225^{\circ} \mathrm{C}$ of $26.7 \pm 2.5 \mathrm{ka}$ and $29.8 \pm 2.7 \mathrm{ka}$, respectively. MA protocols and fading-corrected SAR pro- tocols for IRSL at $50^{\circ} \mathrm{C}$ and post-IR IRSL at $225^{\circ} \mathrm{C}$ are also in agreement within the 1-sigma standard deviation. An age underestimation of $5.4 \%$ was calculated for the MA IRSL but TL age overestimation of $5.6 \%$ was calculated for this sample, if compared with the fading-corrected IRSL age estimates.

Samples Sc 40-44 were taken from the uppermost part of the profile between $9.80 \mathrm{~m}$ and $13.20 \mathrm{~m}$. IRSL age estimates range from $18.1 \pm 2.1 \mathrm{ka}$ to $19.0 \pm 1.8 \mathrm{ka}$ (MA regeneration) and from $18.0 \pm 2.1 \mathrm{ka}$ to $18.9 \pm 2.2 \mathrm{ka}$ (MA additive dose) whereas TL age estimates are between $23.5 \pm 5.4 \mathrm{ka}$ and $24.5 \pm 2.8 \mathrm{ka}$ (MA regeneration) and between $22.1 \pm 2.1 \mathrm{ka}$ and $21.4 \pm 1.9 \mathrm{ka}$ (additive dose). Neither IRSL nor TL data indicates age increase with depth. Sample Sc 42 was further studied. IR at $50^{\circ} \mathrm{C}$ and post-IR IRSL at $225^{\circ} \mathrm{C}$ yielded IRSL age estimates of $23.6 \pm 2.7 \mathrm{ka}$ and $25.8 \pm 2.2 \mathrm{ka}$, respectively. IRSL and TL show a significant age underestimation for sample Sc 42, if compared with the fading-corrected IRSL at $50^{\circ} \mathrm{C}$ and post-IR IRSL at $225^{\circ} \mathrm{C}$ age estimates. IRSL age underestimation exceeds the 1-sigma standard deviation but is in agreement within the 


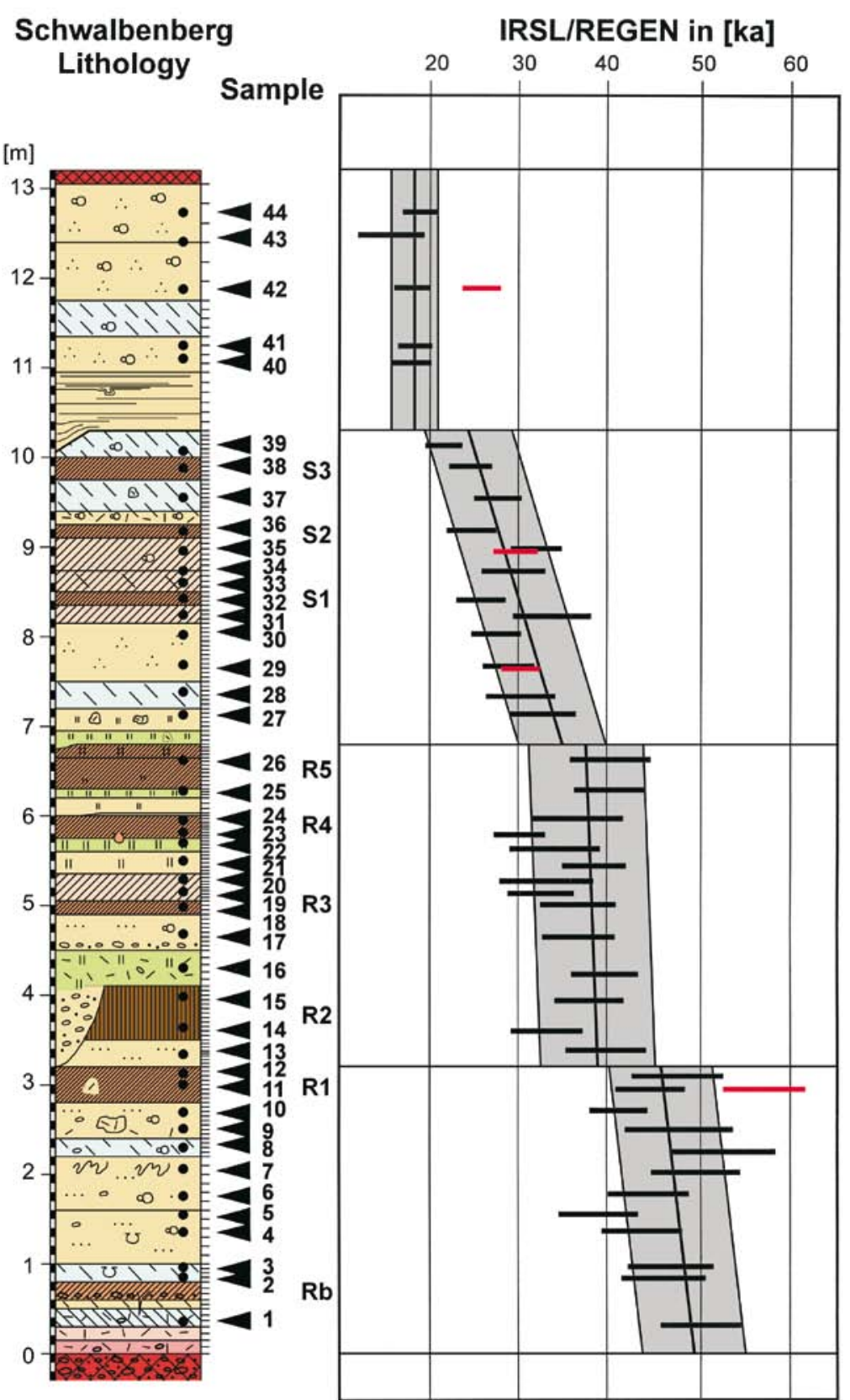

Fig. 5: MA IRSL age estimates (black) and fading corrected post-IR at $225^{\circ} \mathrm{C}$ age estimates (red). $R b=$ Reisberg Soil, $R 1-5=$ Remagen Soils 1-5, S 1-3 = Sinzig Soils 1-3. Legend see Fig. 3.

Abb. 5: Multiple Aliquot IRSL-Alter (schwarzer Balken) und fading-korrigierte post-IR IRSL $\left(225^{\circ} \mathrm{C}\right)$-Alter (roter Balken). $R b=$ Reisberg-Boden, R1-5 = Remagen-Böden 1-5, S1-3 = Sinzig-Böden 1-3. Legende siehe Abb. 3. 2-sigma standard deviation. The MA TL age estimates are in agreement with the fading-corrected age estimates.

\section{Discussion}

The upper part of the penultimate glacial fluvial deposits (below m 0) is truncated, resulting in a hiatus (Keldach Discordance), which includes at least parts of the last interglacial (MIS 5e) and early last glacial record (MIS 5d-a).

The lower part ( 0.00 to $3.20 \mathrm{~m}$ ) of the loess/palaeosol sequence correlates to the Keldach Formation. The oldest loesslike sediments yielded IRSL and TL age estimates ranging from about 55 to $50 \mathrm{ka}$ at its base. The fading-corrected IRSL age (SAR IR at $50^{\circ} \mathrm{C}$ ) gave $53.9 \pm 4.7 \mathrm{ka}$ and the post-IR IRSL $\left(225^{\circ} \mathrm{C}\right)$ yielded $55.5 \pm 4.5 \mathrm{ka}$. These ages are rather young for early MIS 4 deposits, that start with 74-79 ka after ice core ages. Moreover, the luminescence ages of this lower loess may contain tendencies being even younger owing to the solifluidal facies of this lower loess, which very likely results in insufficient bleaching prior to deposition (which does re- sult in age overestimation). Thus, this physical data rise the cautious question whether this lower loess could be an additional part of the Ahrgau Formation (MIS 3).

From litho-pedological aspect this lower loess unit is assigned by SCHIRMER (1990: 107, 1991, 2000a, 2000b, 2002, 2010 and 2011) to the Weichselian Lower Pleniglacial (MIS 4) for the following reasons:

- The widely distributed early loess between the Rocourt Solcomplex (MIS 5) and the soil complex of the Ahrgau Formation (MIS 3) is extraordinary thick here.

- Schirmer (2000a, b, 2011) suggested, that the Ahrgau-Formation with its soils matches excellently to the range of the Greenland Interstadials 17 to 6 by its account of soils, vertical distance of the soils, their rhythmic arrangement and their intensity indicated by the soil property curves. Thus, following Schirmer (2011), the lower loess must be older than GIS 17, and hence at least of MIS 4 age.

- Moreover, the loess facies of this lower loess is throughout solifluidal loess, which is typical for the Keldach Formation (MIS 4) in whole central Europe. 
Tab. 3: $D_{e}$ values and age estimates, as determined by the SAR protocol for IR at $50^{\circ} \mathrm{C}$ and post-IR IRSL at $225^{\circ} \mathrm{C}$ including fading-corrected age estimates. Tab. 3: $D_{e}$-Werte und Alter mittels SAR-Protokolle für IR $\left(50^{\circ} \mathrm{C}\right)$ und post-IR IRSL $\left(225^{\circ} \mathrm{C}\right)$ bestimmt sowie die fading-korrigierten IRSL-Alter.

\begin{tabular}{|c|c|c|c|c|c|c|c|}
\hline \multirow{2}{*}{$\begin{array}{l}\text { Sample } \\
\text { ID }\end{array}$} & \multicolumn{3}{|c|}{ Post-IR IRSL at $225^{\circ} \mathrm{C}$} & \multicolumn{4}{|c|}{ IR at $50^{\circ} \mathrm{C}$} \\
\hline & Mean De [Gy] & g-value & $\begin{array}{l}\text { Uncorrected } \\
\text { pIRIR Age [ka] }\end{array}$ & Mean De [Gy] & g-value & $\begin{array}{l}\text { Uncorrected } \\
\text { IR50 Age [ka] }\end{array}$ & $\begin{array}{l}\text { Fading-correct- } \\
\text { ed IR50 Age [ka] }\end{array}$ \\
\hline Sc42 & $76.5 \pm 1.8$ & $0.8 \pm 0.1$ & $24.1 \pm 2.1$ & $60.6 \pm 0.5$ & $2.4 \pm 0.1$ & $19.1 \pm 2.2$ & $23.6 \pm 2.7$ \\
\hline Sc35 & $108.0 \pm 4.2$ & $0.6 \pm 0.1$ & $28.3 \pm 2.6$ & $88.6 \pm 4.9$ & $1.6 \pm 0.3$ & $23.2 \pm 2.1$ & $26.7 \pm 2.5$ \\
\hline Sc29 & $112.5 \pm 2.5$ & $0.6 \pm 0.1$ & $29.1 \pm 2.5$ & $93.7 \pm 4.8$ & $2.5 \pm 0.1$ & $24.2 \pm 2.2$ & $30.3 \pm 2.7$ \\
\hline Sc11 & $159.8 \pm 3.9$ & $0.3 \pm 0.1$ & $55.5 \pm 4.5$ & $129.2 \pm 7.1$ & $2.0 \pm 0.2$ & $44.9 \pm 3.8$ & $53.9 \pm 4.7$ \\
\hline
\end{tabular}

Tab. 4: Results of performance tests including dose recovery tests and the determination of the residuals.

Tab. 4: Ergebnisse der methodischen Voruntersuchungen inklusive dose recovery tests und das Bestimmen des unbleichbaren Rests („,residuals“).

\begin{tabular}{|c|c|c|c|c|c|c|}
\hline \multirow{2}{*}{$\begin{array}{c}\text { Sample } \\
\text { ID }\end{array}$} & \multicolumn{3}{|c|}{ Post-IR IRSL at $225^{\circ} \mathrm{C}$} & \multicolumn{3}{|c|}{ IR at $50^{\circ} \mathrm{C}$} \\
\hline & $\begin{array}{c}\text { Mean dose recovery } \\
\text { ratio }\end{array}$ & $\begin{array}{l}\text { Dose recovery after } \\
\text { residual subtraction }\end{array}$ & $\begin{array}{l}\text { Mean residual dose } \\
\text { [Gy] }\end{array}$ & $\begin{array}{c}\text { Mean dose recovery } \\
\text { ratio }\end{array}$ & $\begin{array}{l}\text { Dose recovery after } \\
\text { residual subtraction }\end{array}$ & $\begin{array}{c}\text { Mean residual dose } \\
\text { [Gy] }\end{array}$ \\
\hline Sc11 & $0.94 \pm 0.04$ & $0.87 \pm 0.06$ & $6.40 \pm 0.39$ & $0.93 \pm 0.02$ & $0.91 \pm 0.07$ & $1.79 \pm 0.13$ \\
\hline Sc29 & $0.91 \pm 0.01$ & $0.85 \pm 0.15$ & $6.32 \pm 1.15$ & $0.99 \pm 0.02$ & $0.97 \pm 0.04$ & $1.69 \pm 0.06$ \\
\hline Sc35 & $0.94 \pm 0.01$ & $0.89 \pm 0.14$ & $5.54 \pm 0.86$ & $0.89 \pm 0.00$ & $0.88 \pm 0.06$ & $1.85 \pm 0.12$ \\
\hline Sc42 & $0.98 \pm 0.02$ & $0.93 \pm 0.07$ & $4.75 \pm 0.33$ & $0.95 \pm 0.06$ & $0.93 \pm 0.09$ & $1.84 \pm 0.13$ \\
\hline
\end{tabular}

- Also, the grain size curve with coarse silt prevalence and organic carbon curve with low values plead for this assignment (SCHIRMER 2011).

- In addition, the grain size curve shows enhancement of sand in the lower part of this loess unit, which is also a common feature in central Europe (SCHIRMER 2011), whereas sand accumulation from the base of the Middle Pleniglacial soil complex is not recorded.

- The weak Reisberg cambisol fits well to the Keldach Formation, which shows two weak soils in its lower part (SCHIRMER 2002: 19).

- Consequently, from litho-pedostratigraphical point of view a link of the lower loess to the Ahrgau Formation is unlikely.

From a chronological point of view the calculated luminescence age estimates and thus the deposition ages are younger than $60 \mathrm{ka}$, and hence correlate to MIS 3. Furthermore, it is even very likely that the sediments from solifluidal facies are even age overestimated, which would result in even younger deposition ages. As the location of the Schwalbenberg section is close to the river plain and the confluence of rivers Rhine and Ahr, it is very likely that a great part of the sediment is of local origin, hence has undergone a near-distance aeolian transport. This fact would again result in age overestimation of the sediments owing to insufficient bleaching, which was shown for TL age estimates. However, we believe that insufficient bleaching owing to short-distance transport very likely is a minor problem for the sediments under investigation.

The second unit $(3.2-6.8 \mathrm{~m})$, including the Lower and Upper Remagen-Subformation, R1-R5, gives deposition ages around $40 \mathrm{ka}$ by means of litho-pedostratigrapy and chronology. This part of the sequence correlates to the Middle Weichselian Pleniglacial (MIS 3). An age increase with depth is not determined, indicating a relatively fast deposition for the exposed $3.60 \mathrm{~m}$ of sediments. The existence of five fossil brown cambisols (R1-R5) within this unit let us expect a more extended amount of time than the 1-sigma standard deviation of the dating method, which is about $\pm 10 \%$ and thus equals about $8 \mathrm{ka}$ for this unit. These ages of the Remagen Soils are in the range of the lower Middle Weichselian weak brown soil at section Toenchesberg (Boenigk \& Frechen 1999).

The third unit including the three Sinzig Soils or SinzigSubformation (SCHIRMER 2011) between 6.80 and $10.30 \mathrm{~m}$ gives IRSL ages between about 35 and $25 \mathrm{ka}$. The fadingcorrected post-IR IRSL age estimates are about $30 \mathrm{ka}$. An age increase with depth is within the 1-sigma standard deviation indicating a high dust accumulation rate. The Sinzig pedocomplex correlates with the late Middle Weichselian. ZöLLER et al. (1991) reported two TL age estimates from a profile located in the vicinity of the section under study. These two TL age estimates are in good agreement with radiocarbon ages and are within the error in agreement with the results of this study. Finds of Middle to Upper Palaeolithic artifacts, which are contemporaneous with the Aurignacien or Gravettien (App et al. 1987), were investigated from a palaeosol near the Schwalbenberg II section.

The stratigraphically youngermost unit between 10.30 and $13.20 \mathrm{~m}$ gives IRSL and TL age estimates between about 25 and $18 \mathrm{ka}$. The fading-corrected post-IR IRSL at $225^{\circ} \mathrm{C}$ gives deposition ages of about 25 ka making a correlation with the Upper Weichselian most likely. The dust accumulation was most likely very high as no age increase with depth was found for this uppermost unit. The mass ("dust") 
accumulation rates gave high values (FrECHEN et al. 2003) for the area of interest, at least for the Upper Pleniglacial and Late Glacial period.

The Upper Weichselian record is not complete, most likely owing to the morphological position close to the steep cut of the river Rhine. A more complete record for the Upper Pleniglacial was previously described from the right site of the Rhine valley near to the village of Ockenfels (Preusser of Frechen 1999), where several tundra gleysols, a brown arctic meadow and the Eltville Tephra are intercalated in the Upper Weichselian loess.

\section{Conclusion}

The multiple aliquot protocol based IRSL and TL data and those of the single aliquot regenerative protocol based post-IR IRSL at $225^{\circ} \mathrm{C}$ and fading-corrected IR at $50^{\circ} \mathrm{C}$ show that the fading-rate is small for the loess and loess derivatives from the Schwalbenberg II section. The age difference is within the error, the 1-sigma standard deviation, for most of the samples. Our results are in agreement with those of SchmidT et al. (2011) for the Tönchesberg section situated in the East Eifel Volcanic Field. From a stratigraphical point of view, there is disagreement between the litho-pedostratographical and the chronological approach for the stratigraphically oldest unit. the latter one is designated to correlate to MIS 4 by means of litho-pedostratigraphy but gives deposition ages between 55 and $45 \mathrm{ka}$. For the three stratigraphically younger units Middle and Upper Weichselian deposition ages were determined, which is in agreement with the litho-pedostratigraphical approach.

\section{Acknowledgement}

MF appreciates the methodological support and input of Dr. Sumiko Tsukamoto (LIAG) and for providing and explaining the post-IR IRSL data, furthermore for constructive comments of a previous version of the manuscript. We thank an anomymous reviewer for the constructive comments of the manuscript done within 36 hours!

\section{References}

Boenigk, W. \& Frechen, M. (2001): The loess record at sections KoblenzMetternich and Tönchesberg in the Middle Rhine area. - Quaternary International, 76/77: 201-209.

Buylaert, J. P., Murray, A. S., Thomsen, K. J. \& Jain, M., (2009): Testing the potential of an elevated temperature IRSL signal from K-feldspar. Radiation Measurements, 44, 560-565.

Frechen, M. (1992): Systematic thermoluminescence dating of two loess profiles from the Middle Rhine Area (F.R.G.). Quaternary Science Reviews, 11, 93-101.

Frechen, M. (1994): Thermolumineszenz-Datierungen an Lössen des Tönchesberges aus der Osteifel.- Eiszeitalter und Gegenwart, 44: 79-93; Hannover.

Frechen, M., Boenigk, W. \& Weidenfeller, M. (1995): Chronostratigraphie des „Eiszeitlichen Lößprofils“ in Koblenz-Metternich. - Mainzer Geowissenschaftliche Mitteilungen, 24: 155-180; Mainz.

Frechen, M., Oches, E.A. \& KohfELD, K.E. (2003): Loess in Europe - mass accumulation rates during the Last Glacial Period. Quaternary Science Reviews, 22, 1835-1857.

Frechen, M., Schweitzer, U. \& ZANDER, A. (1996). Improvements in sample preparation for the fine grain technique. Ancient TL, 14, 15-17.

Huntley, D.J. \& LAmothe, M. (2001). Ubiquity of anomalous fading in Kfeldspars, and the measurement and correction for it in optical dating. Canadian Journal of Earth Sciences, 38, 1093-1106.

Murray, A. S. \& Wintle, A. G. (2000): Luminescence dating of quartz using an improved single-aliquot regenerative-dose protocol. Radiation Measurements, 32, 57-73.

Preusser, F. \& Frechen, M. (1999): Ockenfels. - In: Becker-Haumann, R \& Frechen, M. (eds.): Terrestrische Quartärgeologie - Festschrift Wolfgang Boenigk. Verlag Sven-von-Loga, Köln.

Preusser, F., Degering, D., Fuchs, M., Hilgers, A., Kadereit, A., Klasen, N., KrbetscheK, M., Richter, D. \& Spencer, J. (2008): Luminescence dating: basics methods and application. Quaternary Science Journal (EuG) 57, 95-149.

Schirmer, W. (1990): Schwalbenberg südlich Remagen. - In: Schirmer, W. (ed.): Rheingeschichte zwischen Mosel und Maas. Deuqua-Führer, 1: 105-108; Hannover.

Schirmer, W. (1991): Würmzeitliche Paläoböden am Mittelrhein. - 10. Tagung des Arbeitskreises „Paläoböden“ der Deutschen Bodenkundlichen Gesellschaft vom 30.05.-1.6.1991 in Bonn, Programm und Exkursionsführer: 70-83; Münster.

Schirmer, W. (1995), with contrib. by H. Berendsen, R. Bersezio, A. Bini, F. Bittmann, G. Crosta, W. De Gans, T. de Groot, D. Ellwanger, H. Graf, A. Ikinger, O. Keller, U. Schirmer, M. W. van den Berg, G. Waldmann, L. Wick: Rhein Traverse. - In: Schirmer, W. [ed.]: Quaternary field trips in Central Europe, 1: 475-558; München (Pfeil).

Schirmer, W. (2000a): Rhein loess, ice cores and deep-sea cores during MIS 2-5. - Zeitschrift der Deutschen Geologischen Gesellschaft, 151 (3): 309-332; Stuttgart.

SCHIRMER, W. (2000b): Eine Klimakurve des Oberpleistozäns aus dem rheinischen Löss. - Eiszeitalter und Gegenwart, 50: 25-49; Hannover.

Schirmer, W. (2002): Compendium of the Rhein loess sequence. - In: IKINGER, A. \& SCHIRMER, W. [eds.]: Loess units and solcomplexes in the Niederrhein and Maas area. - Terra Nostra, 2002 (1): 8-23, 102-104; Berlin.

Schirmer, W. (2010): Interglacial complex and solcomplex. - Central European Journal of Geosciences, 2 (1): 32-40. DOI: 10.2478/v10085-0090038-z

Schirmer, W. (2011): Rhine loess at Schwalbenberg II - MIS 4 and 3. - Eiszeitalter und Gegenwart, 60 (1) (this volume).

Schmidt, E., Frechen, M., Murray, A.S., Tsukamoto, S. \& Bittmann, F. (2011): Luminescence chronology of the loess from the Toenchesberg section - a comparison of using quartz and feldspar as dosimeter to extend the age range beyond the Eemian. - Quaternary International, 234 (1-2): 10-22.

SPOoner, N.A., (1994): The anomalous fading of infrared-stimulated luminescence from feldspars. Radiation Measurements 23, 625-632.

Thiel, C., Buylaert, J.P., Murray, A., Terhorst, B., Hofer, I., Tsukamoto, S. \& Frechen, M. (2011a): Luminescence dating of the Stratzing loess profile (Austria) - Testing the potential of an enhanced elevated temperature post-IR IRSL protocol. - Quaternary International, 234 (1-2): 23-31.

Thiel, C., Buylaert, J.-P., Murray, A.S., Terhorst, B., Tsukamoto, S. \& Frechen, M., (2011b): Investigating the chronostratigraphy of prominent palaeosols in Lower Austria using post-IR IRSL dating. - Quaternary Science Journal, 60 (1).

Thomsen, K. J., Murray, A. S., Jain, M. \& Bøtter-Jensen, L. (2008): Laboratory fading rates of various luminescence signals from feldspar-rich sediment extracts. Radiation measurements, 43, 1474-1486.

Wallinga, J., MurrayA.S. \& Wintle, A.G. (2000): The single-aliquot regenerative-dose (SAR) protocol applied to coarse-grain feldspar. Radiation Measurements, 32: 529-533.

Wintle, A.G. (1973): Anomalous fading of thermoluminescence in mineral samples. Nature, 245, 143-144.

ZÖller, L., CONARD, N.J. \& HAHn, J. (1991): Thermoluminescence dating of Middle Palaeolithic open air sites in the Middle Rhine Valley/Germany. - Naturwissenschaften, 78: 408-410. 